\title{
Adobe as a resilient material and the causes of its disappearance in construction
}

\section{El adobe como material resiliente y las causas de su desaparición en la construcción}

VÁZQUEZ-TORRES, María del Rayo, CASTILLO-REYES, Alberto Rosendo, NAVA-RAMÍREZ, Rosario and MONTERO-URRUSQUIETA, Rubén Ángel

Benemérita Universidad Autónoma de Puebla

ID $1^{\text {st }}$ Author: María del Rayo, Vázquez-Torres / ORC ID: 0000-0002-3509-2684, Research ID Thomson: U-8561-2018, CVU CONACYT ID: 508248

ID $1^{\text {st }}$ Coauthor: Alberto Rosendo, Castillo Reyes / ORC ID: 0000-0001-6338-2534, Research ID Thomson: U-9440-2018, CVU CONACYT ID: 950754

ID $2^{\text {nd }}$ Coauthor: Rosario, Nava-Ramírez / ORC ID: 0000-0003-2222-3187, CVU CONACYT ID: 165145

ID $3^{\text {rd }}$ Coauthor: Rubén Ángel, Montero-Urrusquieta / ORC ID: 0000-0001-6325-2238, CVU CONACYT ID: 599097

\section{Abstract}

The objective of this research is to value adobe constructions as buildings that must be preserved. The method applied to this research is qualitative, the objective is the description of the characteristics depending on the areas involved in resilience inductively, resulting from the proximity to empirical reality in municipalities of the state of Puebla, Mexico. The field research was conducted in Atlixco, Huaquechula, Tochimilco and Chietla, all municipalities in the State of Puebla and were used as examples as a result of direct observation. The stages of the research were: bibliographic analysis on the subject, the fieldwork was established with the planning of the fieldwork, data collection where instruments of different types were applied in each municipality and finally the systematization of the data from the fieldwork. It had the support of brigade groups from the Benemérita University of Puebla, BUAP and professors from the same institution.

Concept, Material, Fatores

\section{Resumen}

El objetivo de esta investigación es valorar a las construcciones de adobe como edificaciones que se deben conservar. El método aplicado a esta investigación es de carácter cualitativo, el objetivo es la descripción de las características en función de las áreas que implica la resiliencia de forma inductiva, resultado de la proximidad a la realidad empírica en municipios del estado de Puebla, México. La investigación de campo, se realizó en Atlixco, Huaquechula, Tochimilco y Chietla, todos municipios del Estado de Puebla y se utilizaron como ejemplos como resultado de la observación directa. Las etapas de la investigación fueron: análisis de bibliográfica sobre el tema, el trabajo de campo se estableció con la planificación del trabajo de campo, recolección de datos donde se aplicaron instrumentos de diferente tipo en cada municipio y por último la sistematización de los datos procedentes del trabajo de campo. Se tuvo el apoyo de grupos brigadistas de la Benemérita Universidad de Puebla, BUAP y profesores de la misma institución.

Concepto, Material, Fatores

Citation: VÁZQUEZ-TORRES, María del Rayo, CASTILLO-REYES, Alberto Rosendo, NAVA-RAMÍREZ, Rosario and MONTERO-URRUSQUIETA, Rubén Ángel. Adobe as a resilient material and the causes of its disappearance in construction. Journal of Architecture and Design. 2021, 5-13: 38-50

*Correspondence to Author (e-mail: mrayovt@gmaill.com)

$\dagger$ Researcher contributing as first author. 


\section{Introduction}

The concept of resilience began to be used in physics, but it was adopted by medicine, psychology, industrial engineering, civil engineering, architecture and is currently used in all branches of science. Adobe is classified as a vulnerable material, since the idea that adobe constructions are fragile and of poor quality has been promoted, however, there are constructions that have responded very well to earthquakes. Therefore, it is advisable to understand what are the causes that affect buildings made with adobe to solve the problems. The sections included in this work are the concept, the material and the fathers. In the case of the concept of resilience, its definition, antecedents of the moment in which it arises and the characteristics that a resilient material must contemplate are established. In the area of the material its characteristics are defined and shown according to the resilience. Finally, the most important factors that allow the disappearance of adobe constructions are established.

\section{The concept}

Resilience has been defined from different fields such as the study of stress and the effects of stress on the heart, and has been expressed as the ability to prepare, recover and adapt to stress, challenges or adversity. (Insttute of HeartMath, 2014, page 1)

Likewise, from psychology, resilience has been considered as an interactive mechanism between the psychological qualities of the subject and the risk factors that allows the protection of the family, social and cultural environment. The strategies that are developed to face adverse situations are not permanent, as they change according to experiences and temporal and spatial conditions. Currently resilience is conceived as a universal quality that is inherent to nature and therefore to the human being; as well as the way in which they have faced adversities of different kinds and are progressing culturally... "Resilience is a positive and hopeful approach to the possibilities of leading a normal life in a disadvantaged environment, as well as the ability to cope, of recovery and even of positive transformation and enrichment of the human being after having suffered traumatic experiences". (Uriarte, 2005)
With respect to the perspective of international organizations such as UNESCO, it defines resilience as the confrontation with crises from a social and universal position, as a complex system; whose main challenges focus on reducing poverty and mitigating natural hazards and climate change, based on the relationships between the city and humanity ... "Resilience is the capacity of a system, a community or a society exposed to the risks of resisting, absorbing, accommodating and recovering from the effects of a hazard in a timely and efficient manner, including through the preservation and restoration of their essential basic structures and functions ". (UNESCO Mexico, 2020)

Without a doubt, the concept of resilience focuses on overcoming crises and surviving; often exceeding the limits of recovery, in a reconstruction process that affects psychological well-being, with the vision that all stages of life can be changed and improved. People and groups of people develop protection mechanisms that allow them to overcome the stress of chaotic situations. Although, it should be noted that a protection mechanism can become a risk factor or a risk factor can become a protection mechanism. (Rutter, 1990)

All of these reasons had their beginning in the 1980s when Emily Wernery introduced the concept of resilience. At that time, the closest concept was that of invulnerability. The difference between both concepts is that invulnerability is permanent, but resilience is never permanent and absolute since it can vary depending on the aggression, age or situation in which the individual finds himself; facilitating the individual's resistance to adversity and enabling him to respond immediately. Later, in 1982, the concept of resilience was introduced into psychology from the studies of E.E. Werner and R.S. Smith, at that time the concept of vulnerability predominated. The concept of resilience was associated with three research areas: 1) risk, vulnerability and invulnerability factors and protection mechanisms; 2) innate and acquired mechanisms in the processes of vulnerability and invulnerability and 3) individual differences in the way of evolving and facing difficult situations. The study of personality, autonomy and self-esteem was developed; 
These concepts made it possible to form the notion of resilience and apply it to other areas of knowledge. The resilient personality is associated with temperament and character traits such as autonomy, a positive social attitude, and one's own emotional control. Selfesteem and the feeling of self-efficacy are some of the personal characteristics that allow us to face problems and protect ourselves from adversity and in turn favor psychological balance. As a result, 4 areas of application were defined: biological, family, micro-social and macro-social, where all areas are related to each other. In the biological field, people can have congenital or acquired somatic handicaps of different origin and their condition has not limited them to have a decent life.

In this case, the family supports the person and facilitates their insertion in different aspects of life. In the case of the micro-social sphere, the conditions of the environment with deficiencies and circumstances provoke a state of "social aggression". In relation to the implications of the macrosocial, historical or public sphere, it is related to survival in situations of natural catastrophes, wars, terrorism, deportations, among other aspects. (Uriarte, 2005)

Considering the above, it can be said that in the face of the chaos that occurs in catastrophes, protective factors are also developed to neutralize risk factors and these are present in the process of resilience. These processes can be developed in different ways according to the characteristics of the societies; that is, while they are more united, it allows them to cope with difficulties and together they generate emotional and material ties to help each other.

Among the members of the family, regardless of its structure, the family continues to be the social nucleus that allows the individual to have a space of refuge in personal difficulties and is the support for new projects. The construction of resilience transcends the family sphere to the community, since both individuals and families are comforted and supported economically and socially among their relatives, neighbors, groups and associations. (Uriarte, 2005, page 72)
This is observed in many communities in the country, where they meet to solve problems in the countryside, economic problems and even build houses with their own hands. Also, several families live in the same lot and they all help each other to survive, dividing the tasks and if any member migrates to other locations, they send income so that their family can better cope with their living conditions. It has also been observed in Mexico that indigenous community food producers group together to protect themselves, such is the case of the Association of Indigenous Producers of Popocatépetl, Organic Bee Honey Producers in Mexico, agave producers, coffee producers, among many others. groups that currently exist. They also meet to support their religious group, an example of this is in the Barrio San Juan Bautista, a town closest to the active Popocatépetl volcano. The temple was located on Calle San Juanito, Tochimilco, the patronal feast of San Bautista is celebrated on June 23, where it is tradition that the musicians of the area meet in the atrium and play music.

In 2017, in the first months, they gathered economic resources from the community and even from migrant relatives who sent money for the party. The men, women and children contributed to paint the temple, however, due to the earthquake, the temple collapsed, currently the inhabitants of that community have gathered economic resources, materials and labor that the community contributes for the construction of a new temple.

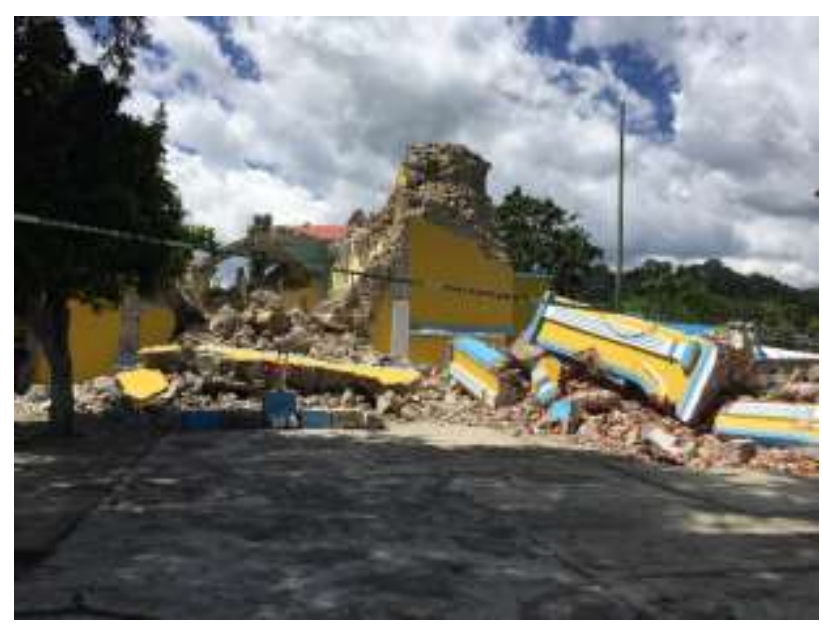

Figure 1 Temple of San Juan Bautista, painted for the celebration of August 15 affected by the earthquake of September 19, 2017 
The concept of resilience is relatively new in the fields of architecture, urban planning and territorial urban planning, constituting one of the key elements of the concept of urban ecology and sustainability. Various researchers have suggested that for truly resilient cities to exist, it is necessary for buildings to be built with resilient materials. The resilience of materials does not involve the ability of a material to withstand tensile, compressive, bending, torsional and shear stresses. The resilience of materials is based on the elasticity of materials, where their mechanical properties allow large deformations to return to their original state. (Cortés, 2015)

It is common for resilience to be confused with the resistance of materials, therefore, it is said that adobe is not a resilient material because its mechanical characteristics are insufficient to resist telluric phenomena; However, in seismic areas there are constructions of more than four centuries that still stand.

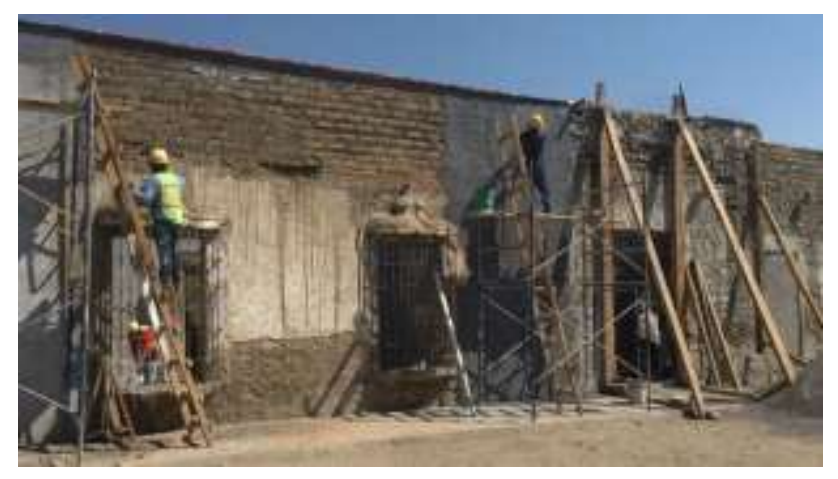

Figure 1 Historic dwelling. Huaquechula, Puebla, 2017

According to the concept of resilience, a material is considered to be resilient because the elasticity of the material is a property that allows it to recover its original shape after being subjected mainly to seismic forces when those forces stop acting on it, recovering their dimensions.

Another fundamental aspect that involves the concept of resilience, is to anticipate and mitigate the risks to which the buildings are exposed. Consequently, materials that have a higher resistance index electrical power can be considered more resilient than that they are good drivers, since in a situation of catastrophe, by 'isolating' electricity, they protect their habitants. Architecture, if it intends to be resilient, you must use materials that are excellent insulators of electricity
Although elasticity is essential in a resilient material, it is not the only aspect that is related to the resilience of materials, another characteristic of resilience is to anticipate and mitigate the risks to which constructions are exposed. Among the properties that a resilient material must have is electrical resistance because in catastrophic situations, it is important that the material protects its inhabitants from electricity. Another characteristic that a resilient material must have is its thermal property; when their dimensions are modified when their molecules separate, they cause a decrease in their density and therefore their capacity to transport heat inside the construction decreases. Regarding the environmental category, a resilient material must have the following characteristics: nontoxic, recyclable, reusable and biodegradable. (Cortés, 2015)

It should be considered that the resistance of a material to withstand tensile, compressive, flexural, torsional and shear stresses is not a requirement for resilience.

Before entering into consideration of the above, it is necessary to mention that there are few official guidelines to determine the conditions of the adobe; The ONNCCE norms, in Mexico it does not include a norm on adobe, but there is norm E.080 of Peru.

"The standard refers to the mechanical characteristics of materials for the construction of reinforced earth buildings, the earthquake resistant design for reinforced earth buildings, the fundamental structural elements of reinforced earth buildings as well as the behavior of adobe walls. and mud, according to the earthquake resistant design philosophy ". (Ministry of Housing, Construction and Sanitation; 2017, page 4)

\section{The material}

The adobe allows to elaborate simple artisan masonry, its components vary according to the region, but the basic compounds are earth, straw and water until a uniform and malleable mixture is achieved that is placed in wooden molds to create the adobe pieces and they are left to dry while free air from 30 days to 60 days. 
As mentioned above, adobe masonry has disadvantages compared to annealed clay and concrete masonry, due to its resistance to bending, shear and axial compression forces being very low. Also, it presents erosion due to the action of thermal inertia. (Catalan, Moreno, Arroyo \& Galván, A., 2019)

In the case of adobe, the E.080 standard refers to the admissible forces: Compressive strength of the unit fo $=12 \mathrm{~kg} / \mathrm{cm}^{2}$; Masonry compressive strength $\mathrm{fm}=0.2 \mathrm{f}$ ' $\mathrm{mo}=2 \mathrm{~kg}$ / $\mathrm{cm}^{2}$; Compressive strength by crushing foap = $1.25 \mathrm{fm}$ and Shear strength of masonry $\mathrm{vm}=$ $0.25 \mathrm{~kg} / \mathrm{cm}^{2}$.

On the other hand, in the tests carried out by Catalán, Moreno, Arroyo \& Galván, A. in 2019 with adobe batteries or prototypes in Guerrero, Mexico, they found the following: "All adobe blocks presented resistance higher than that specified in the Standard E. 080, which indicates a minimum compressive strength of $12 \mathrm{~kg} / \mathrm{cm}^{2}$ ". The average value in flexural strength was obtained was $8.02 \mathrm{~kg} /$ $\mathrm{cm}^{2}$ and the water absorption was $14.91 \%$. They found that the mechanical properties of adobe are very low, mainly the bending stress, since there is little adherence when cement mortar is used for the joints, but they are within the admissible range.

The partition walls have a shear stress:

\begin{tabular}{|l|l|}
\multicolumn{1}{|c}{ Wall type } \\
\hline Red septum & \multicolumn{1}{c|}{.m $^{2}$} \\
\hline $\begin{array}{l}\text { Clay partition with vertical } \\
\text { gaps }\end{array}$ & $\begin{array}{l}2 \text { to } 3 \text { depending on the } \\
\text { biker used }\end{array}$ \\
\hline Heavy concrete block & $\begin{array}{l}2.5 \text { to } 3.5 \text { depending on } \\
\text { the biker used }\end{array}$ \\
\hline Concrete partition (partition) & 2 to 3 \\
\hline Adobe & 1.12 \\
\hline
\end{tabular}

Table 1 Shear stress $(\mathrm{Vm}) \mathrm{kgf} / \mathrm{cm}^{2}$ (UNIFED, 2015)

Also, it was admitted that adobe is hygrophilic because it absorbs atmospheric humidity, likewise it affects the humidity of the ceilings and foundations for the loss of cohesion and resistance; when the block is moistened it loses resistance and mass as it crumbles. This situation occurred in the Historical and vernacular housing constructions in the 2017 earthquake and the damages were catastrophic for this type of constructions.

\begin{tabular}{|l|l|}
\hline \multicolumn{1}{|c|}{ Adobe Features } & \multicolumn{1}{c|}{ Values } \\
\hline Permeability index & $1 / 1,000,000 \mathrm{~cm} / \mathrm{s}$ \\
\hline Water absorption. & 5 to $8 \%$ dry weight \\
\hline $\begin{array}{l}\text { Linear shrinkage coefficient } \\
\text { (unstabilized) }\end{array}$ & $3 \mathrm{~mm} / \mathrm{m}$ \\
\hline Acoustic isolation & $\begin{array}{l}58 \mathrm{~dB}(\mathrm{f}=500 \mathrm{~Hz}, \text { wall } \\
50 \mathrm{~cm})\end{array}$ \\
\hline Young's modulus & $\begin{array}{l}10,000 \text { to } 70,000 \mathrm{Kg} / \\
\mathrm{cm}^{2}\end{array}$ \\
\hline Fire resistance & $\begin{array}{l}\text { Mud is not considered } \\
\text { combustible, even when } \\
\text { lightened with straw }\end{array}$ \\
\hline
\end{tabular}

Table 2 Adobe Features. (Architects sen fronteiras, s / f, page 9)

If these data are compared with the data for the average adobe $(\mathrm{Vm})$ of $0.11 \mathrm{MPa}$ that corresponds to $1.12 \mathrm{kgf} / \mathrm{cm}^{2}$, the modulus of elasticity is very low, however, this does not mean that the material does not have a good response to its recovery. shape.

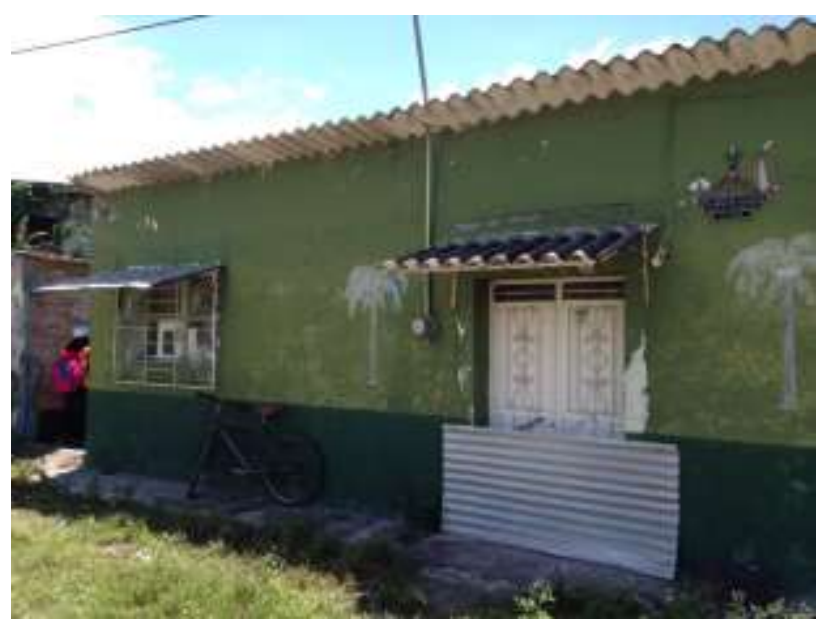

Figure 3 Adobe house in Chietla, the epicenter of the 2017 earthquake that was not affected, due to its construction quality. Buap, 2017

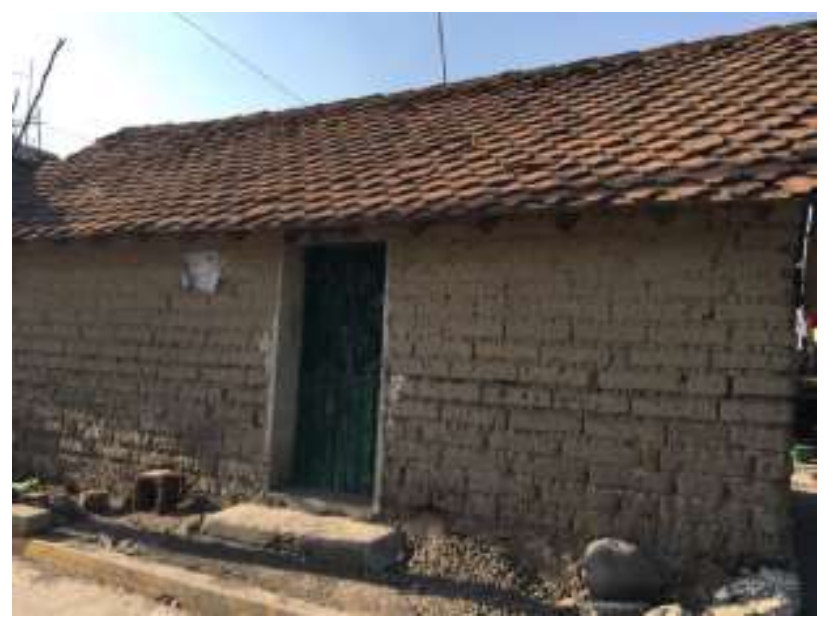

Figure 3 Adobe house that was not affected, due to its construction quality. Huaquechula, Puebla, 2017 
On the other hand, resistance is a measure of the opposition to the flow of current in an electrical circuit, it is said that all materials resist the flow of current to some extent. This resistance is measured in ohms (Greek letter omega $\Omega$ ) ... "As indicated by Ohm's Law, resistivity is a volumetric property of the material and indicates its resistance to the passage of electrical charges." (Andrade and D’Andrea, 2011, page 95)

Even though it is an important characteristic, studies on adobe are focused on its physical and mechanical characteristics, which is why it is necessary to evaluate the values of electrical resistance. These elements are joined by the thermal property, which can be defined as the form of response to changes in temperature, the forms of response are related to their expansion and contraction. The data of the thermal characteristics of adobe:

\begin{tabular}{|l|l|}
\hline \multicolumn{1}{|c|}{ Adobe } & \multicolumn{1}{c|}{ Value } \\
\hline Thermal conductivity & $0.5 \mathrm{Kcal} / \mathrm{hm}^{\circ} \mathrm{C}$ \\
\hline Specific heat & $0.2 \mathrm{Kcal} / \mathrm{Kg}^{\circ} \mathrm{C}$ \\
\hline $\begin{array}{l}\text { Global transmission } \\
\text { coefficient }\end{array}$ & $\begin{array}{l}0.8 \mathrm{Kcal} / \mathrm{hm}^{2}{ }^{\circ} \mathrm{C} \text { (for a 50 } \\
\mathrm{cm} \text { wall) }\end{array}$ \\
\hline $\begin{array}{l}\text { Thermic dilatation } \\
\text { coefficient }\end{array}$ & $0.012 \mathrm{~mm} / \mathrm{m}^{\circ} \mathrm{C}$ \\
\hline
\end{tabular}

Table 3 Thermal values according to information from Arquitectos sen fronteiras, (s / f, page 9)

\begin{tabular}{|l|r|}
\hline Thermal conductivity & $\mathbf{W} / \mathbf{~}^{\mathbf{2}} \mathbf{K}$ \\
\hline Insulating partition & 0.15 \\
\hline Red septum & 0.6 \\
\hline Concrete & 0.8 \\
\hline Adobe & 0.176 \\
\hline
\end{tabular}

Table 4 Thermal conductivity. Table prepared with data from Holguino, Olivera, \& Escobar. (2018)

Therefore, it can be observed that adobe has a higher thermal conductivity value than that of the red partition and insulating partition, but lower than that of concrete.

Finally, the environmental category will be addressed, related to the concept of sustainability. Using the definitions of Catalán, Moreno, Arroyo \& Galván, A. (2019), it can be said that in the environmental category adobe is resilient because it is not a toxic material, it does not produce a great impact on the environment and it is biodegradable, it is not poisonous, it does not pollute water, soil and atmosphere.
In addition, it has recycling capacity and can be subjected to a new manufacturing process, in terms of reuse, it is the ability to be used after disassembly; In this case, the adobe depends on the state of the block and is a biodegradable material as it decomposes by a natural biological process; therefore, it can be considered as a sustainable material.

Sustainability has been defined by the $\mathrm{UN}$ as the satisfaction of current needs without compromising the ability of future generations to meet theirs, guaranteeing the balance between economic growth, care for the environment and social well-being.

From a sustainable material point of view, the adobe manufacturing process does not require fuel, it only requires ventilation and sunlight to dry. As mentioned previously, adobe has the capacity to store heat during the hours of sunlight and release that energy towards its interior when the temperature drops outside. Due to the fact that it is a material that absorbs atmospheric humidity, it allows to keep the interior humid, even in times when the environment is dry, which is why it is less frequent to observe cracks due to thermal changes in this type of material. Due to its thickness and sound characteristics, adobe makes it an acoustic insulator, it is noncombustible, the material does not contain toxins that harm living beings and, as mentioned before, it is a material with a certain degree of recycling and the excess material during its process can be returned to the environment.

It is also a material that belongs to the constructive, social and cultural tradition of rural communities, it allows them to have an identity. This constructive tradition has been recognized by INAH because it already includes houses built with adobe and bajareque, as Mexican cultural heritage and is part of the cultural identity of the communities and its disappearance causes the deterioration of the national cultural wealth. (PASTOR, s / f)

\section{The factors}

Among the causes that allow the loss of vernacular architecture that influence its disappearance are: modernity, globalization, the media, the impact of migration on architecture, housing programs and environmental actions. 
Among these, the most influential are the idea of modernity, the media, housing programs, and environmental actions. In this regard, the current concept of modernity has to do with a concept or idea that seeks to build the present thinking towards the future (Díaz Espinoza, 2013), where its objective is the homogenization of life forms and according to the criteria established according to this approach, development is measured. It is currently related to globalization, the media and the development programs of each country, covering the social, political and cultural organization and especially the economic organization. (Marín and Morales, 2010)

Likewise, the media transmit the concepts of modernity, globalization and detachment from the constructive tradition. In the case of modernity, the diffusion in the government media of its housing programs directed at architectural forms and construction processes that show aspects of progress in other parts of the planet is observed; which are not related to the reality of the majority of the population. The companies that produce materials and construction of houses also use the media to spread the idea that there are better ways to build... "The values associated with socio-economic progress and democratic culture penetrate into the lives of families and environments immediate social activities: school, community services, social coexistence". (Uriarte, 2005)

Thus, the buildings that are shown in the media become an ideal, because they are recognized as expressions of socioeconomic development, which is why the better the economic position, the more one looks at the ways of life of those who are at the top. This is observed in populations where there is migration, where the relatives of migrants modify their homes with a mixture of styles that they saw in the places where they worked and the more traditionalists modify their home to have more rooms, apply income to the maintenance or improvement of conditions existing.

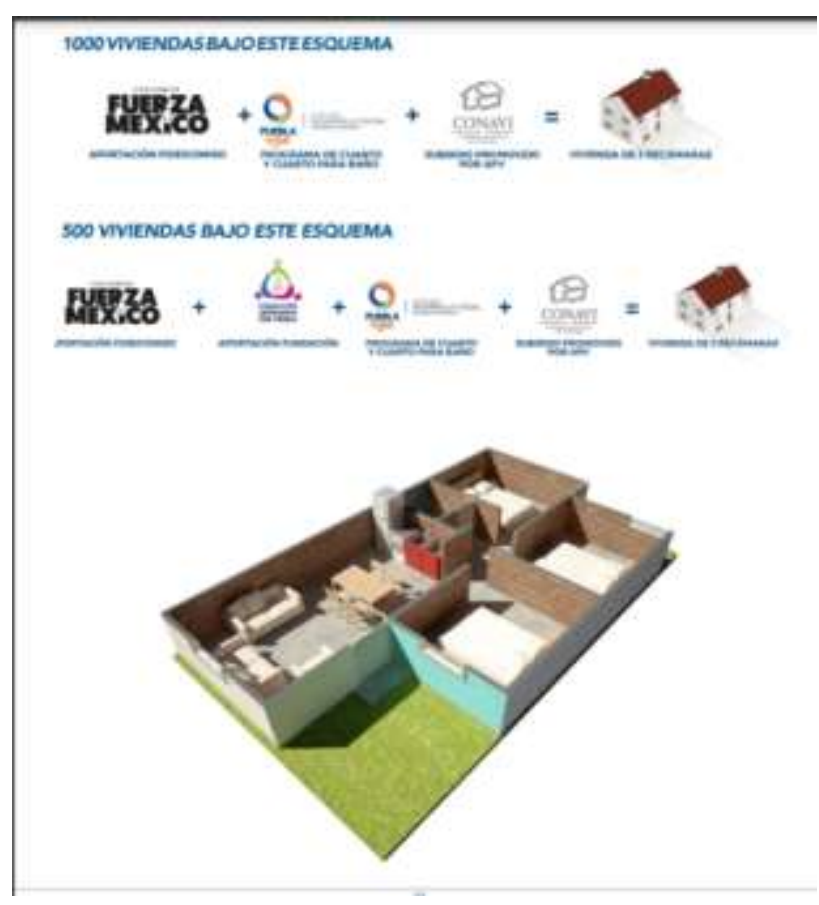

Figure 5 Propaganda for the reconstruction of houses in Puebla, houses damaged by the earthquakes of September 9 and 19, 2017 (State Commission for Reconstruction, Puebla, 2018)

In addition to the above, globalization appears as a process of interconnection in the world where it encompasses economic, political, social and technological aspects and its main tool has been digital communication ... "Globalization under the influence of the economic aspect is born with trade international and it was expanding until producing the mobility of the factors of production in the world, resizing the geopolitical distribution of the factors of production in the world. " (Flores, 2016, pp. 26-41)

Digital communication breaks down borders and it is among young people where there is more concern to live as they live in other countries and these in turn modify the architecture according to parameters of other places and other cultures, rejecting adobe constructions.

Adobe was used in Mexico for a long time as the primary material of traditional construction; however, it is currently seen as a poor quality material and construction system by architects and government institutions. This is shown in the criteria used for the taking of censuses and urban development reports, where vernacular architecture is seen as a symbol of poverty. 
In population and housing censuses, housing is classified by the criteria of architectural design, age, location, precariousness, ethnic identity or culture, where inadequate, lagging or precarious housing are identified.

As well as construction materials, equipment, goods and characteristics of people, to distinguish different forms of room. The unit dwellings of the collectives are also identified, where the spaces and the type of private dwelling are classified according to the type of construction, access, independence or grouping, purpose of the building or improvisation in its occupation.

It should be noted that in the information from INEGI (2021), those homes that were built with resistant materials by a construction company are recognized as quality homes, as well as private homes of fixed construction that are part of a group of homes grouped in the same land as is the case of many vernacular dwellings. In the case of materials, industrialized, traditional, natural or waste materials are included.

Within the data collection it is assumed that industrialized materials are more resistant and durable than natural or waste materials; Although it is recognized that the quality of housing is conditioned by climatic aspects and construction tradition as an expression of cultural identity, it is still related to poverty and housing backwardness.

The interest about building materials, especially the walls in houses, was collected in Mexico for the first time in 1950 and the concepts about materials were changing as shown in Table 5.

\begin{tabular}{|c|c|c|}
\hline Census & Walls & Covers \\
\hline $\begin{array}{l}1950 y \\
1960\end{array}$ & $\begin{array}{l}\text { Open question about the } \\
\text { predominant material. }\end{array}$ & $\begin{array}{l}\text { Open question about } \\
\text { the predominant } \\
\text { material. }\end{array}$ \\
\hline 1970 & $\begin{array}{l}\text { The classification of } \\
\text { adobe walls, partition or } \\
\text { similar materials, wood, } \\
\text { mud and other materials } \\
\text { were included. }\end{array}$ & $\begin{array}{l}\text { There were five options } \\
\text { (concrete and the like; } \\
\text { straw, palm and the } \\
\text { like, tile, wood or } \\
\text { others). }\end{array}$ \\
\hline 1980 & $\begin{array}{l}\text { Materials such as } \\
\text { cardboard sheet, reed, } \\
\text { bamboo or palm, asbestos } \\
\text { or metallic sheet were } \\
\text { added and bajareque was } \\
\text { included in the garbage } \\
\text { option. }\end{array}$ & $\begin{array}{l}\text { Materials such as } \\
\text { cardboard sheet and } \\
\text { asbestos or metallic } \\
\text { sheet, concrete } \\
\text { materials, the shingle } \\
\text { and wood with the } \\
\text { palm were included. }\end{array}$ \\
\hline 1990 & $\begin{array}{l}\text { The option was } \\
\text { simplified and partition, } \\
\text { brick, block, stone or } \\
\text { concrete walls were } \\
\text { grouped. }\end{array}$ & $\begin{array}{l}\text { Simplified to concrete } \\
\text { slab, partition or brick }\end{array}$ \\
\hline 1995 & There were no changes. & $\begin{array}{l}\text { The concept of waste } \\
\text { material was added and } \\
\text { the roof with a beam } \\
\text { was grouped with } \\
\text { concrete slab, partition } \\
\text { and brick. }\end{array}$ \\
\hline 2000 & $\begin{array}{l}\text { waste material was } \\
\text { incorporated, the option } \\
\text { "other materials" } \\
\text { eliminated. }\end{array}$ & There were no changes. \\
\hline 2010 & There were no changes. & $\begin{array}{l}\text { The type of materials is } \\
\text { specified and the types } \\
\text { of wood palm and } \\
\text { tejamanil were joined } \\
\text { as they are considered } \\
\text { similar; separating the } \\
\text { roof with beams and } \\
\text { the concrete slab } \\
\text { because they are } \\
\text { different construction } \\
\text { techniques. }\end{array}$ \\
\hline 2015 & There were no changes. & $\begin{array}{l}\text { The fiber cement sheet } \\
\text { option was added and } \\
\text { the bricked roof over } \\
\text { beams was eliminated } \\
\text { as it is considered a } \\
\text { vulnerable system to } \\
\text { earthquakes. }\end{array}$ \\
\hline
\end{tabular}

Table 5 Changes in the classification of wall and roof materials with information from INEGI (2021)

In the 2015 Intercensal Survey, the option "fiber cement sheet" was added as its use was supported in Emergency Care programs and the Program for the Development of Priority Zones.

These materials were included and considered optimal for use in the roofs of the houses, their cost, installation time, insulation, durability and lightness. On the other hand, the bricked roof on beams was eliminated as it was considered a vulnerable system to earthquakes and in a certain way degrading it to a system of low construction quality. 
In the case of flats, it is related to the housing backwardness, since it influences the protection, hygiene and health of people, and is a necessary variable for estimating indicators of marginalization, social backwardness, poverty and adequate housing. For this reason, the development of concrete pavements was supported in the Firm Floors Program. (INEGI, 2021). Next, you can see how they simplified the indicators from 1980 to 2020 for Puebla: in 1980 there were different types of materials and currently they have been grouped into resistant materials (reinforced concrete slab, coffered slab or joist and vault for roofs and partition, partition, block for the roofs) and others where handicraft and recycling materials are grouped. However, this information is used to determine, for example, that the use of adobe in 1980 was $25.30 \%$ of utilization, in 2020 the use of adobe, wood, reed, mud or bajareque among other materials is only $6.70 \%$.

\begin{tabular}{|c|c|c|c|c|c|c|}
\hline Concept & 1980 & 1980 & 1980 & 2020 & 2020 & 2020 \\
\hline & Walls & Covers & Floors & Walls & Covers & Floors \\
\hline Cardboard sheet & 2.8 & 13.28 & & & & \\
\hline $\begin{array}{l}\text { Palm, shingle or } \\
\text { wood }\end{array}$ & & 7.18 & & & & \\
\hline $\begin{array}{l}\text { Asbestos sheet } \\
\text { or metallic }\end{array}$ & 0.96 & 12.28 & & & & \\
\hline Roof tile & & 23.68 & & & & \\
\hline $\begin{array}{l}\text { Concrete slab, } \\
\text { brick vault, roof, } \\
\text { brickwork on } \\
\text { beams }\end{array}$ & & 39.68 & & & & \\
\hline Other materials & 1.13 & 1.17 & & 6.7 & 20.9 & \\
\hline Not specified & 1.26 & 2.73 & & & & \\
\hline $\begin{array}{l}\text { Carrizo, bamboo } \\
\text { or palm }\end{array}$ & 5.2 & & & & & \\
\hline $\begin{array}{ll}\begin{array}{l}\text { Embarro } \\
\text { bajareque }\end{array} & \text { or }\end{array}$ & 2.06 & & & & & \\
\hline Wood & 18.84 & & & & & \\
\hline Adobe & 25.3 & & & & & \\
\hline $\begin{array}{l}\text { Resistant } \\
\text { materials: } \\
\text { partition, } \\
\text { partition, block } \\
\text { etc. }\end{array}$ & 42.45 & & & 93.3 & & \\
\hline Earth & & & 36.44 & & & 5.1 \\
\hline Cement or firm & & & 34.57 & & & \\
\hline $\begin{array}{l}\text { Mosaic or other } \\
\text { coating }\end{array}$ & & & 26.79 & & & \\
\hline $\begin{array}{l}\text { Unspecified } \\
\text { floor }\end{array}$ & & & 2.2 & & & \\
\hline $\begin{array}{l}\text { Resistant } \\
\text { materials: } \\
\text { Reinforced } \\
\text { concrete slab, } \\
\text { coffered slab or } \\
\text { joist and vault }\end{array}$ & & & & & 79.1 & \\
\hline $\begin{array}{l}\text { Cement, firm or } \\
\text { coated floors }\end{array}$ & & & & & & 94.9 \\
\hline
\end{tabular}

Table 5 Construction materials with information from INEGI (2021)
With the information from the censuses, urban development strategies are established and in the case of institutions in charge of housing, the use of industrialized materials is encouraged, not only because they are considered more durable and safer, but also because they raise development levels. from the country.

This situation is clearly seen in the 2020 census where the following data are observed: Homes with one bedroom $34.10 \%$; houses with 2 bedrooms $39.10 \%$; homes with 3 bedrooms $20.50 \%$, homes with 4 bedrooms $4.80 \%$ and homes with 5 bedrooms or more with $1.40 \%$. Regarding the materials used in construction: cement or firm $62.20 \%$; partition walls, brick, stone, quarry, cement or concrete $93.30 \%$ being relegated the adobe along with the so-called natural materials; In the case of reinforced concrete ceilings and joist and vault roofs, this corresponds to $79.10 \%$, relegating the beam and sheet systems to $20.90 \%$.

Due to the above, it can be affirmed that artisan architecture is disappearing, among other causes, due to the vision that institutions have regarding this architecture as buildings without quality with materials that are not resistant.

On the other hand, advertising supports this position that adobe is a vulnerable material, as it has been widely disseminated by companies that produce industrialized materials and by the government, such as the 2017 earthquake, President Enrique Peña Nieto stated that " According to reports from military engineers and the state's civil protection area, in addition to the force of the earthquake, the fall of houses was mainly due to the fact that they are made of adobe and have poor foundations. " (Zatarain, 2017)

From an economic point of view it coincides with the way in which houses and the form of construction are classified, since previously: "The social fabric of previous years made possible a diversity of economic interactions, where some people made adobes, others tiles, and others provided their construction services". 
If the adobe construction system were promoted, the economic interaction of local agents could generate local development, since the products and services would be acquired within the same community, providing employment to the people and using low-cost local materials. The concept has been used that during the earthquakes the most affected houses are made of adobe because of its fragility.

However, it is not mentioned that many of the buildings destroyed during the earthquakes were made of materials that are called resistant such as concrete and it is attacked that the constructions of artisanal materials or of vernacular housing lacked foundations; This hides a great problem that is the lack of supervision in construction and therefore the use of construction techniques without quality. (PASTOR, s / f) All constructions have a "useful life", during this period problems of progressive instability arise, since the materials are affected by various causes that cause their deterioration. In addition to this, interventions and lack of maintenance can generate serious problems that are evidenced by weathering that reduces the capacity of materials and by earthquakes. (De La Torre, López, Salazar, \& Roldán, 2004)

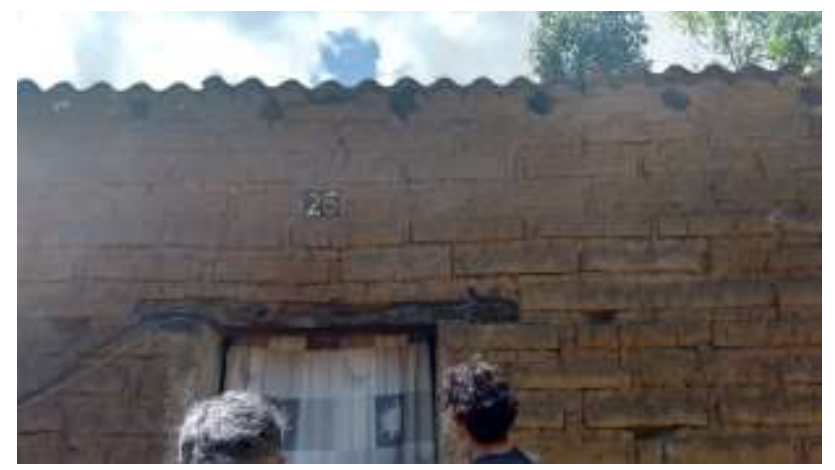

Figure 6 Door lintel damaged by weathering that affects its useful life in San Juan Bautista, Tochimilco, Puebla, 2017

This could be evidenced in the 2017 earthquake in populations that were visited such as Atlixco, Tochimilco, Huaquechula and Chietla, where different problems were found that together caused damage and even the total destruction of the buildings. A common problem was that the intervention in the buildings weakened their structure by eliminating supports, walls or annexing rooms, or the walls were perforated to place sanitary, hydraulic or electrical installations.
Walls were also weakened by enlarging windows and opening doors, or reinforced concrete elements were integrated by modifying their configuration.

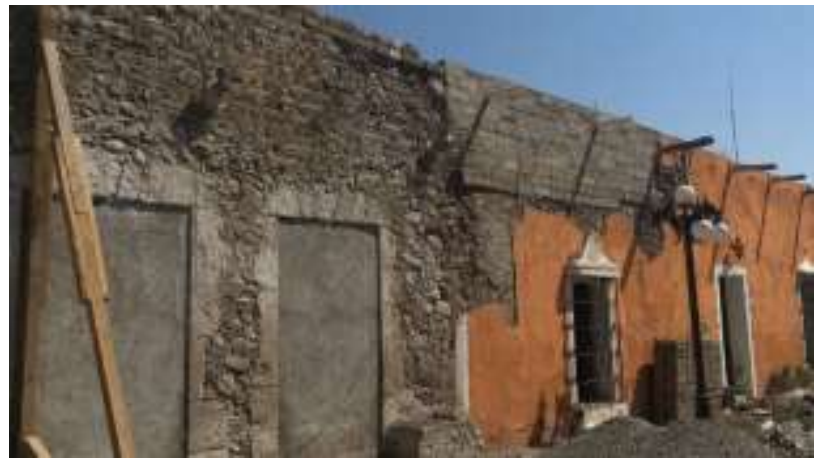

Figure 7 After the 2017 earthquake, the parapets came off in buildings classified as historical heritage, which is why different materials were used in the intervention. In the case of the house on the right, it was made of a parapet with hollow cement blocks, which is a material incompatible with adobe. Atlixco, Puebla, 2017

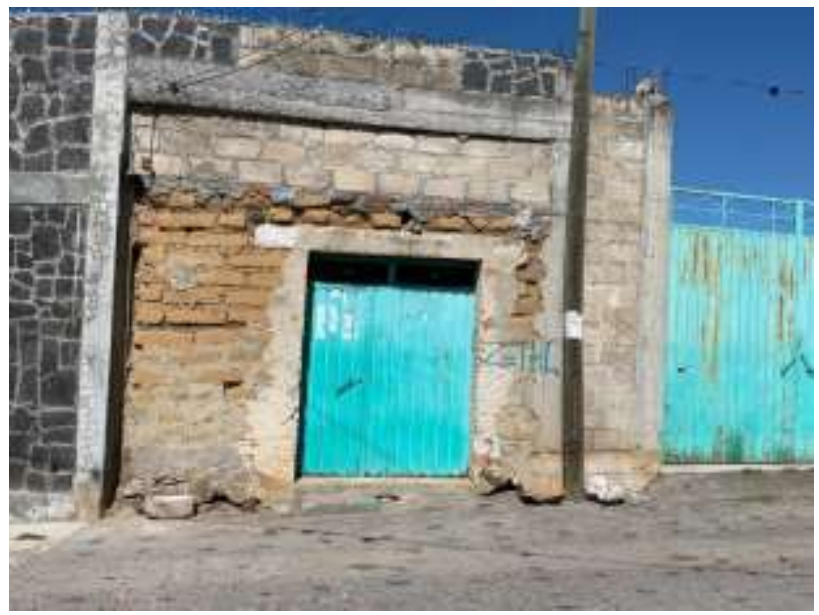

Figure 8 Adobe house with interventions using, heavy block, stone and the inclusion of columns, chains and beams that modify its configuration. Huaquechula, Puebla, 2017

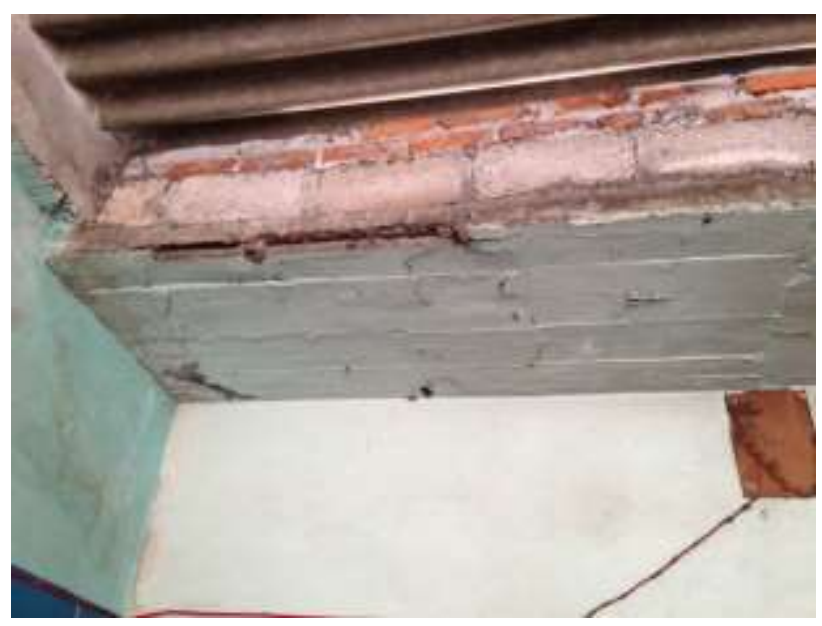

Figure 9 Adobe house in Chietla, the epicenter of the 2017 earthquake, where reinforced concrete slab was incorporated. Buap, 2017

VÁZQUEZ-TORRES, María del Rayo, CASTILLO-REYES, Alberto Rosendo, NAVA-RAMÍREZ, Rosario and MONTEROURRUSQUIETA, Rubén Ángel. Adobe as a resilient material and the causes of its disappearance in construction. Journal of Architecture and Design. 2021 
Regarding environmental actions, they are the ones that most influence the disappearance of adobe constructions since they are interrelated and made up of climatic actions (temperature, sunlight, water, wind, ice, earthquakes and impact loads); polluting actions (soluble salts, volcanic ash and acid rain; biological actions (bacteria and fungi, lichens, algae and mosses, plants, animals) and biological actions (vandalism, over-exploitation of the structure, accidents, interventions and lack of maintenance).

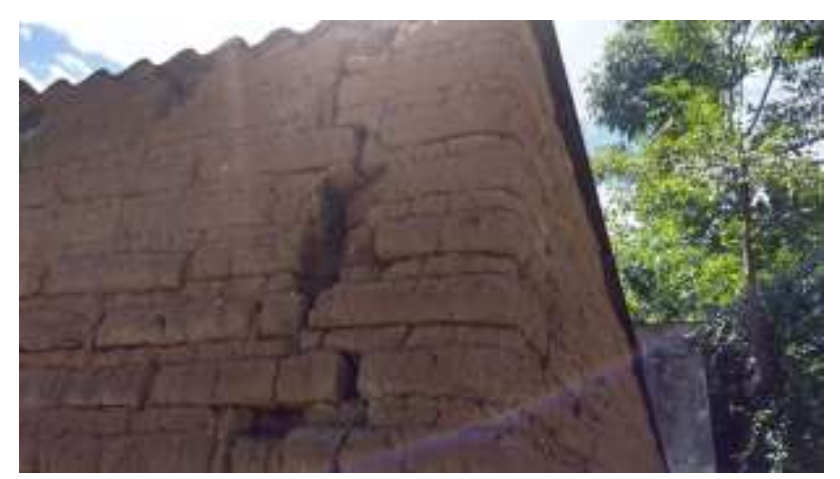

Figure 10 Housing in the neighborhood of San Juan Bautista, affected by the earthquake of September 19, 2017. Tochimilco, Puebla, 2017

Originally the adobe was originally joined with clay mortars, however, later cement containing soluble salts was used, this was later eliminated from the cements, but caused the adobe to weaken or disintegrate or sandblast some blocks. Acid rain occurs when the humidity of the air combines with nitrogen oxides, sulfur dioxide or sulfur trioxide, also, the wind deposits these particles and when it rains they degrade the adobe. Sandblasting occurs inside and on top of it the material is apparently not damaged as a hardened crust is generated on the exposed part.

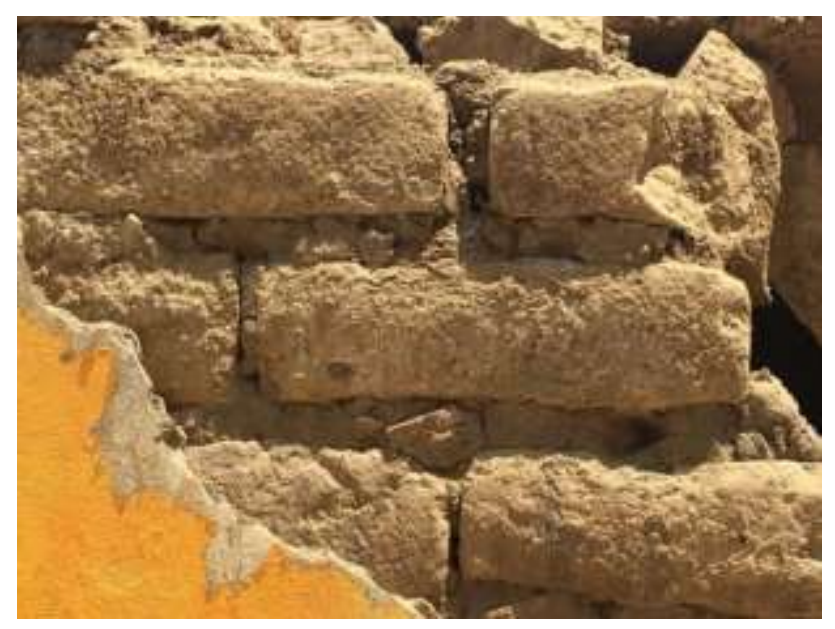

Figure 11 Clay mortar that joins the adobe in a historic building. Tochimilco, Puebla, 2017

ISSN 2531-2162

ECORFAN® Todos los derechos reservados
Erosion due to mechanical causes, rain and changes in temperature form fissures or spaces where spores are deposited by the wind and algae or lichens grow as a result of humidity. In turn, this material becomes food for insects, birds or rodents. Also, nearby plants or trees can grow and crack the walls when looking for water through which the water seeps (DE LA PEÑA, 1997).

After the 2017 earthquake, it was observed in Atlixco, Tochimilco, Huaquechula and Chietla that there were buildings that collapsed both adobe constructions and those built with "resistant" materials. The vernacular and historical architecture suffered serious interventions despite the fact that there were buildings classified as historical heritage. These situations have caused the loss of adobe homes, it has not been possible to establish since the 2020 census was suspended due to the pandemic and there are still no results that allow comparing the information from the 2015 census. However, it was also possible to see that adobe constructions with quality construction processes remained in good condition despite being affected by seismic forces.

\section{Conclusions}

It should be recognized that adobe is a material that has resistance values lower than the resistance values of the partition wall and industrialized materials, but they are also different types of constructions. There are constructions from 4 centuries ago that have been able to withstand the latest earthquakes such as the Puebla earthquake of September 19, 2017 with a magnitude of $7.1 \mathrm{Mw}$.

Handmade materials have practical advantages, since these materials are used in construction processes that belong to their tradition. Also, these materials are environmentally friendly from the point of view of energy saving; that is to say, they absorb the temperature from the outside, it is absorbed by the material and then it is displaced inwards by the changes from the outside; they provide warmth when it's cold and cool when it's hot. This is called knowledge or constructive tradition. 


\section{References}

ANDRADE y D'ANDREA; La resistividad eléctrica como parámetro de control del hormigón y de su durabilidad; Revista ALCONPAT, Volumen 1, Número 2, MayoAgosto 2011, Páginas 93 - 101

ARQUITECTOS SEN FRONTEIRAS, Ficha técnica: sistema constructivo adobe/tapial, Proxecto coñecemento da realidade [PCR]| Programa OXLAJUJ TZ'IKIN|ASFE |ASIAPRODI, S/F, http://www.galicia.asfes.org/wpcontent/uploads/2016/09/04-Ficha-TecnicaAdobe-Tapial.pdf

\section{ARROYO MATUS, ROBERTO Y SÁNCHEZ TIZAPA, SULPICIO Y CATALÁN QUIROZ, POLICARPO (2013), "Caracterización experimental de las propiedades mecánicas de la mampostería de adobe del sur de México". Ingeniería, Vol. 17, núm.3, pp.167-177 [Consultado: 16 de Septiembre de 2021]. ISSN: 1665-529X. Disponible en: https://www.redalyc.org/articulo.oa?id=467309 14001}

COMISIÓN ESTATAL PARA LA RECONSTRUCCIÓN, PUEBLA, Informe sismo $19 \mathrm{~s}$ recopilación sectorial de actividades en el proceso de reconstrucción de puebla reconstrucción, Secretaría de gobernación, 2018.

CATALÁN-QUIROZ, P., MORENOMARTÍNEZ, J. Y., ARROYO MATUS, R., \& GALVÁN, A. (2019). Obtención de las propiedades mecánicas de la mampostería de adobe mediante ensayes de laboratorio. Acta Universitaria 29, e1861. doi. http://doi.org/10.15174.au.2019.1861

CORTÉS, Oscar; Propiedades que definen los materiales resilientes en arquitectura, Revista de Tecnología, Journal of Technology Volumen 14, Número 1, Págs. 117-126, Junio 2015. https://www.researchgate.net/publication/30627 5421_Propiedades_que_definen_los_materiales _resilientes_en_arquitectura_Defining_the_mat erials_properties_resilient_in_architecture

PEÑA, D. (1997). Adobe, características y sus principales usos en la construcción. Puebla: Instituto tecnológico de la construcción.
DE LA TORRE Rangel, O., LÓPEZ Vázquez, R., Salazar Hernández, A., \& Roldán Cabrera, J. C. (2004). Evaluación estructural y comportamiento de las reparaciones efectuadas a edificaciones históricas. Revista de Ingeniería Sísmica, núm. 70, enero-junio, 2004, 1-26.

DÍAZ Espinoza, R. (2013). El proyecto filosófico de la modernidad y su crítica desde el exterior constitutivo ,. Revista Contextualizaciones latinoamericanas, Año 5, número 9, julio-diciembre, 2013, 1-7.

FLORES, María Victoria, la globalización como fenómeno político, económico y social Orbis. Revista Científica Ciencias Humanas, vol. 12, núm. 34, 2016, pp. 26-41

HOLGUINO Huarza, Antonio, OLIVERA Marocho, Luis, \& ESCOBAR Copa, Katterine Ursula. (2018). Confort térmico en una habitación de adobe con sistema de almacenamiento de calor en los andes del Perú. Revista de Investigaciones Altoandinas, 20(3), 289300. https://dx.doi.org/10.18271/ria.2018.394

INEGI, Censo de Población y Vivienda (2020). Censo de Población y Vivienda 2020: marco conceptual / Instituto Nacional de Estadística y Geografía.-- México : INEGI, c2021.

INSTTUTE OF HEARTMATH, Guía Construyendo Resiliencia Personal, Habilidades HeartMath para la Efectvidad Personal, 2014, www.heartmath.org Publicado por el Insttute of HeartMath.

MARÍN Bravo, Á., \& MORALES Martín, J. (2010). Modernidad y modernización en América Latina; una vaentura inacabada. Roma: Critical Journal of Social and Juridical Sciences, 26 (2) .

\section{MINISTERIO DE VIVIENDA,} CONSTRUCCIÓN Y SANEAMIENTO, norma E.080 diseño y construcción con tierra reforzada, 2017.

PASTOR, Diana, El adobe no es pobreza, es resilencia, Entre mundos, s/f, https://www.entremundos.org/revista/economia /adobe-no-pobreza-resilencia/ 
REVISTA ELECTRÓNICA \#IE, El adobe, el material de construcción de moda, práctico y sostenible, s/f, https://ielektro.es/2019/12/03/adobe-materialconstruccion-moda/

RUTTER, M. (1993). Resilience; some conceptual considerations. Journal of Adolescent Health. 14, 8, págs. 626-631

UNESCO, Naciones Unidas México, Destaca UNESCO México la resiliencia de las ciudades en el combate contra COVID-19, 12 mayo 2020. https://www.onu.org.mx/destaca-unescomexico-la-resiliencia-de-las-ciudades-en-elcombate-contra-covid-19/

UNIFED, Normas y especificaciones para estudios, proyectos, construcción e instalaciones, volumen 4. Seguridad estructural, 2015.

URIARTE Arciniega, Juan de D. La resiliencia. Una nueva perspectiva en psicopatología del desarrollo Revista de Psicodidáctica, vol. 10, núm. 2, 2005, pp. 61-79 Universidad del País Vasco/Euskal Herriko Unibertsitatea VitoriaGazteis, España.

V. Flores, S. Sánchez-Tizapa, R. Arroyo, R. Barragán, Propiedades mecánicas de la mampostería de tabique rojo recocido utilizada en Chilpancingo, Gro (México), Informes de la Construcción, Vol. 65, 531, 387-395, julioseptiembre 2013. ISSN: 0020-0883. eISSN: 1988-3234. doi: 10.3989/ic.12.084

ZATARAIN, Karina. "Peña Nieto afirma erróneamente que 'la caída de viviendas [tras el sismo en Oaxaca] se debió a que están hechas de adobe'" 23 sep 2017. ArchDaily México. Accedido el $7 \quad$ Sep 2021. <https://www.archdaily.mx/mx/880216/penanieto-afirma-erroneamente-que-la-caida-deviviendas-tras-el-sismo-en-oaxaca-se-debio-aque-estan-hechas-de-adobe> ISSN 0719-8914 